\title{
Recovering Turkish narrow clawed crayfish (Astacus leptodactylus) populations carry Aphanomyces astaci
}

\author{
H. Kokko(1), L. Koistinen ${ }^{(1)}$, M.M. Harlioğlu(2), J. Makkonen ${ }^{(1)}$, H. Aydın ${ }^{(3)}$, \\ J. Jussila $a^{(1)^{*}}$
}

Received December 15, 2011

Revised January 25, 2012

Accepted March 6, 2012

\section{Abstract}

Key-words: $\quad$ Crayfish stocks collapsed in Turkey in mid 1980's due to crayfish plague Aphanomyces astaci, narrow clawed crayfish, Turkey, İznik, Hirfanlı epidemics, with up to $25 \%$ survival in some cases. The collapsed stocks have then recovered slowly and commercial crayfish fishery was reinitiated gradually within a decade. We examined the prevalence of Aphanomyces astaci DNA in the narrow clawed crayfish (Astacus leptodactylus) collected from two Turkish lakes, Lake İznik and Hirfanlı Dam ( $N=40$ from both sites). The qPCR results, verified by conventional PCR and sequencing, indicated that nearly all sampled crayfish were $A$. astaci carries with some of them showing gross symptoms of infection, such as tissue erosion and melanisation, while some did not show any visible symptoms. The prevalence of A. astaci DNA was high in both stocks, being on the average $95 \%$ in both Lake Iznik and Hirfanlı Dam. Our results show that these stocks are carries of $A$. astaci, but capable of forming productive stocks which indicates past and contemporary partial resistance adaptation in the host or virulence evolution in the $A$. astaci.

\section{RÉSUMÉ}

Des populations turques d'écrevisses à pattes grêles (Astacus leptodactylus) productives porteuses d'Aphanomyces astaci

Mots-clés : Les stocks d'écrevisses se sont effondrés en Turquie à la mi 1980, en raison des Aphanomyces astaci, écrevisseà pattes grêles, Turquie, İznik, épidémies de peste des écrevisses, avec jusqu'à $25 \%$ de survie dans certains cas. Les stocks qui se sont effondrés ont ensuite récupéré lentement et la pêche commerciale des écrevisses a été relancée progressivement au cours d'une décennie. Nous avons examiné la prévalence de l'ADN d'Aphanomyces astaci dans les écrevisses à pattes grêles (Astacus leptodactylus) prélevées dans deux lacs turcs, İznik et Hirfanli ( $N=40$ des deux sites). Les résultats de qPCR, vérifiés par PCR conventionnelle et séquençage, ont indiqué que presque toutes les écrevisses échantillonnées étaient porteuses d' $A$. astaci, certaines d'entre elles présentant des symptômes graves d'infection, tels que l'érosion des tissus et la mélanisation, tandis que d'autres ne présentent pas de symptômes visibles. La prévalence de l'ADN

(1) Department of Biology, University of Eastern Finland, Kuopio campus, P.O. Box 1627, 70211 Kuopio, Finland

(2) Fisheries Faculty, Firat University, 23119 Elaziğ, Turkey

(3) Gazanfer Bilge Vocational School, Kocaeli University, Karamürsel, Kocaeli, Turkey

*Corresponding author: japo.jussila@uef.fi 
d'A. astaci était élevée dans les deux stocks, étant en moyenne de $95 \%$ dans les deux lac İznik et le barrage Hirfanli. Nos résultats montrent que ces stocks sont porteurs d'A. astaci, mais capables de former des stocks productifs ce qui traduit une adaptation passée et contemporaine par résistance partielle de l'hôte ou une évolution de la virulence d'A. astaci.

\section{INTRODUCTION}

Crayfish plague (Aphanomyces astaci), an oomycete, has caused population collapses among most native European freshwater crayfish stocks since 1860's (Souty-Grosset et al., 2006) and largely eradicated productive stocks from the continental Europe. Water bodies in British Isles, Norway and Turkey remained long the last safe havens for the European crayfish (Souty-Grosset et al., 2006) until mid 1980's, after which many productive native narrow clawed crayfish (Astacus leptodactylus) stocks collapsed in Turkey (Holthuis, 1961; Rahe and Soylu, 1989; Harlioğlu, 2004). As a result, the crayfish trapping and export ceased from Turkey to Europe. The stock collapses in Turkey were partial in some water bodies with up to $25 \%$ survival (Harlioglu and Harlioglu, 2006; Bolat et al., 2011).

The collapsed narrow clawed crayfish stocks have later recovered substantially in Turkey (Harlioğlu and Harlioğlu, 2004; Güner and Harlioğlu, 2010), but are often still showing severe gross disease symptoms, such as melanisation and erosion of the tail (Baran and Soylu, 1989a; Rahe and Soylu, 1989; Harlioğlu, 2004). Similar symptoms have been described in the signal crayfish (Pacifastacus leniusculus) non-lethally carrying the crayfish plague ( $A$. astaci) (SoutyGrosset et al., 2006). Recently, even the highly vulnerable noble crayfish (Astacus astacus) have been found to be able to carry the disease without acute mortality (Jussila et al., 2011b; Viljamaa-Dirks et al., 2011), and there are indications of increased resistance towards certain strains of $A$. astaci isolates in the noble crayfish (Makkonen et al., manuscript in preparation). Such findings suggest that the host-parasite relationship of $A$. astaci and European crayfish might have evolved during the rapid adaptation of $A$. astaci during its 150 year presence in Europe (Jussila et al., 2011b). It is predicted that the virulence of a disease causing very high mortality would decrease over time, since, for the fitness of the disease, it is crucial to maintain suitable environment, i.e. have hosts. Such development of virulence was observed for example in the biological control efforts of rabbits brought to Australia (Kerr and Best, 1998).

The aim of this study was to evaluate the possible presence of $A$. astaci in the traumatized crayfish individuals (melanization, necrosis or erosion of carapace) from selected Turkish water bodies. The information on the possibility of the adaptation of narrow clawed crayfish against crayfish plague as well as them acting carriers after the earlier population collapse (Harlioğlu, 2008) would be essential. This would greatly add to the current knowledge on the co-evolution and host-parasite interaction of $A$. astaci among native European crayfish stocks.

\section{MATERIALS AND METHODS}

\section{> CRAYFISH, SAMPLING LOCATIONS AND SAMPLE PREPARATION}

Crayfish were collected using traps (fyke-net) during summer 2011 from Lake İznik $\left(40^{\circ} 27^{\prime} \mathrm{N}\right.$ $29^{\circ} 32^{\prime} \mathrm{E}$ ) and Hirfanlı Dam (39 $\left.10^{\prime} \mathrm{N} 33^{\circ} 36^{\prime} \mathrm{E}\right)$. A total of 40 narrow clawed crayfish were sampled from both locations. The samples included 20 healthy and 20 with symptoms, of both gender groups. Samples for the qPCR analyses of $A$. astaci were then taken by cutting a piece of uropod from each crayfish. In addition, 10 crayfish showing symptoms were sampled parallel by cutting piece of traumatized tissue. The samples were stored in $99.9 \%$ ethanol (Merck) by the Firat University staff in Turkey. The dissection tools were disinfected after every sampled crayfish tissue. The preserved samples were stored at $-21^{\circ} \mathrm{C}$ and then shipped by airmail to the University of Eastern Finland for further analyses. 


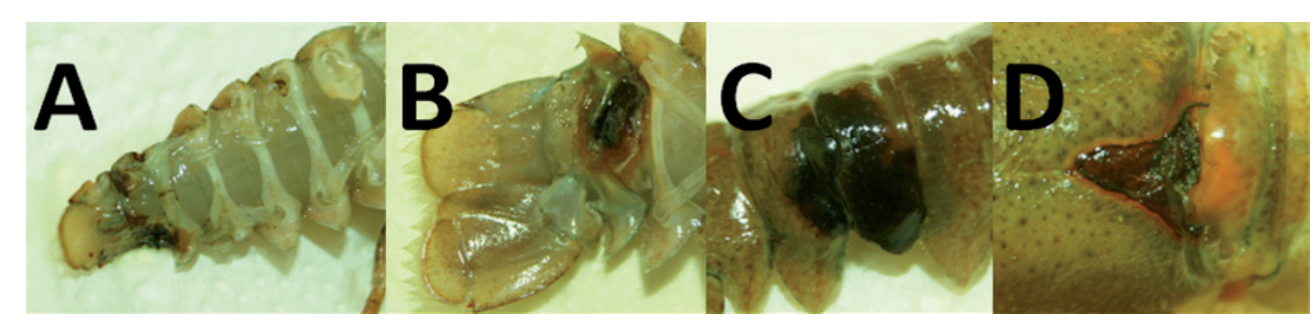

\section{Figure 1}

Typical symptoms with melanised lesions and tissue erosion in the cuticle of the narrow clawed crayfish (Astacus leptodactylus) from Turkey. $A=$ uropod erosion, $B=$ abdominal cuticle melanisation and erosion, $C=$ hard dorsal tail cuticle melanisation and $D=$ carapace melanisation.

The prevalence of disease symptoms, i.e. melanised spots and tissue erosion, among catch during 2010 and 2011 surveys were 10-15\% and 5\% in Lake İznik and Hirfanlı Dam, respectively.

\section{> DNA EXTRACTIONS AND THE DETECTION OF A. ASTACI DNA}

Before the DNA extractions, the tissue samples were rinsed in sterile water to remove the ethanol. DNA extractions were made with E.Z.N.A Insect DNA isolation kit following manufacturer's instructions with the quantity and quality of the extracted DNA been measured with a NanoDrop-spectrophotometer (Thermo Fisher Scientific) (Jussila et al., 2011a). A quantitative TaqMan ${ }^{\circledR}$ minor groove binder (MGB) real-time PCR assay (qPCR) developed by Vrålstad et al. (2009) was used. LightCycler 480 II qPCR machine (Roche) was used and the sample volume was adjusted to $10 \mu \mathrm{L}$. TaqMan ${ }^{\circledR}$ Environmental Master Mix (Applied Biosystems) was used for the qPCR reactions (Strand et al., 2011) and $2 \mu \mathrm{L}$ of $10 \times$ diluted DNA sample (amount of DNA varied from $20 \mathrm{ng}$ to $260 \mathrm{ng}$, being approximately $100 \mathrm{ng}$ per reaction). Calibrated standard curve was used to determine the PFU values and agent levels for samples crayfish tissues.

To confirm the obtained qPCR results six samples with highest agent level in qPCR were selected from both Lake İznik and Hirfanlı Dam amplified with conventional PCR method and sequenced. These DNA samples were isolated from melanized cuticle pieces. The PCR was carried out with primers AAITS39F (Vrålstad et al., 2009) and 640 (Oidtmann et al., 2006). Selected primer pairs amplified $570 \mathrm{bp}$ fragment of $A$. astaci internal transcribed spacers, including partial ITS1 region, 5.8S rDNA gene and partial ITS2 region. Reaction included $2 \mathrm{U}$ Maxima Hot Start Taq DNA polymerase (Fermentas), 1× volume of Maxima Hot Start Taq Buffer (Fermentas), $2 \mathrm{mM} \mathrm{MgCl}_{2}, 1 \mu \mathrm{L}$ of dNTP mix, $10 \mathrm{mM}$ each (Fermentas), $10 \mu \mathrm{M}$ of both primers and $80 \mathrm{ng}$ of template DNA. Reaction volume of $50 \mu \mathrm{L}$ was completed with water. Following program was used with PTC-200 thermal cycler (MJ Research): $95^{\circ} \mathrm{C} 5 \mathrm{~min}, 35 \times$ $\left(95^{\circ} \mathrm{C} 30 \mathrm{~s}, 60^{\circ} \mathrm{C} 45 \mathrm{~s}, 72^{\circ} \mathrm{C} 1 \mathrm{~min} 30 \mathrm{~s}\right)$ and $72{ }^{\circ} \mathrm{C} 10 \mathrm{~min}$. The amplification of PCR products was checked on electrophoresis in $1.5 \%$ agarose gel containing $0.5 \mu \mathrm{\mu g} \cdot \mathrm{mL}^{-1}$ ethidiumbromide. PCR amplicons were purified with QiaQuick PCR purification kit (Qiagen) following manufacturer's instructions. Sequencing was done at A. I. Virtanen Institute, University of Eastern Finland, by using MegaBACE 750 DNA analysis system (Amersham) and AAITS39F was used as sequencing primer. Sequences produced in this study were submitted into GenBank with access numbers JQ434693 and JQ434694.

\section{RESULTS}

The trauma sites showed lesions and tissue erosion in sampled crayfish stocks (Figure 1). The gross symptoms were clear and distinct. Symptoms have clear similarities to those been observed in the Finnish and Estonian crayfish stocks. 


\section{Table I}

Quantitative TaqMan ${ }^{\circledR}$ MGB PCR results of the crayfish plague analyses. Samples taken from uropod and trauma site (melanisation, erosion, etc.). Agent level qPCR rating is according to Vrålstad et al. (2009) and indicated as number of crayfish in each category. A0 are negative subsamples, A1 $<5$ PFU (PCR forming units), 5 PFU $\geq A 2<50$ PFU, 50 PFU $\geq \mathrm{A} 3<10^{3}$, $10^{3} \geq \mathrm{A} 4<10^{4} \mathrm{PFU}, 10^{4} \geq \mathrm{A} 5<10^{5} \mathrm{PFU}$ and $10^{5} \geq \mathrm{A} 6<10^{6} \mathrm{PFU}$. An A2 agent level was considered as a reliable but low-level A. astaci DNA detection.

\begin{tabular}{|l|l|c|c|c|c|c|c|c|c|}
\hline \multicolumn{9}{|c|}{ Proportional qPCR rating, \% } \\
\hline \multicolumn{2}{|c|}{} & $A 0$ & $A 1$ & $A 2$ & $A 3$ & $A 4$ & $A 5$ & $A 6$ \\
\hline Uropod sample & Crayfish with symptoms & 0 & 5 & 25 & 50 & 10 & 10 & 0 \\
\hline \multirow{2}{*}{ Lake İznik } & Crayfish with no symptoms & 5 & 0 & 35 & 60 & 0 & 0 & 0 \\
\hline Hirfanlı Dam & Crayfish with symptoms & 5 & 0 & 45 & 45 & 5 & 0 & 0 \\
\cline { 2 - 11 } & Crayfish with no symptoms & 0 & 0 & 40 & 60 & 0 & 0 & 0 \\
\hline Trauma site sample & 0 & 0 & 10 & 30 & 20 & 20 & 20 \\
\hline Lake İznik & & 40 & 0 & 30 & 30 & 0 & 0 & 0 \\
\hline Hirfanlı Dam & &
\end{tabular}

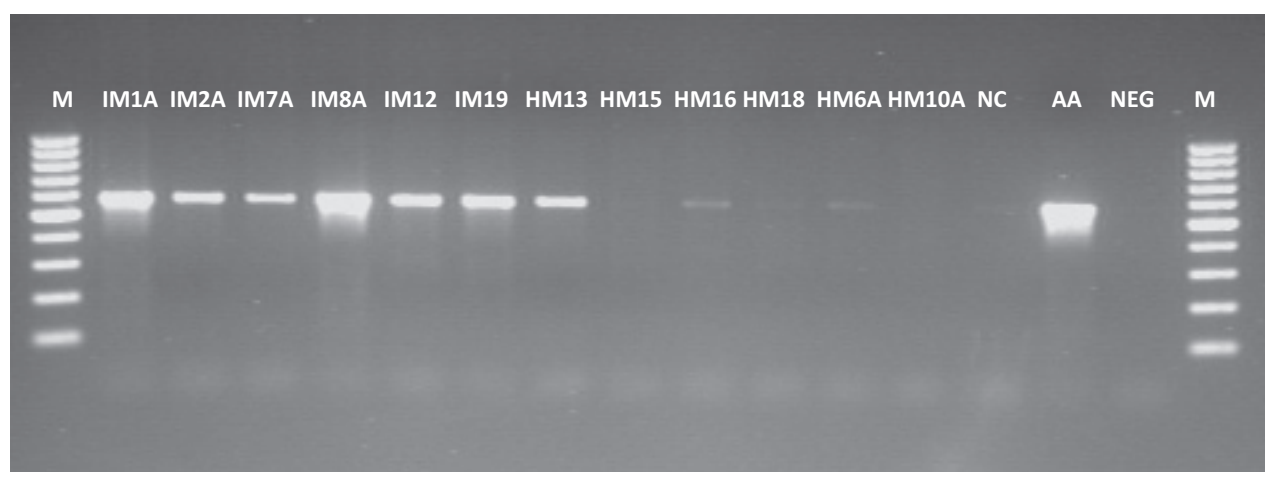

\section{Figure 2}

PCR amplicons (570 bp) obtained with primer pair AAITS39F and 640 (Vrålstad et al., 2009; Oidtmann et al., 2006; respectively). IM = lake Iznik melanisation sample, HM = Hirfanlı Dam melanisation sample, number refers into different crayfish individuals. Controls: $N C=$ noble crayfish, $A A=\mathrm{A}$. astaci, $N E G=$ water as a template .

We detected mostly low to moderate levels of $A$. astaci DNA in uropod samples from both Lake Iznik and Hirfanlı Dam narrow clawed crayfish samples (Table I). Both sampled sites had some crayfish that were discovered healthy while the prevalence of the $A$. astaci DNA detection was 95\% in both Lake İznik and Hirfanlı Dam samples, based on the uropod samples. The prevalence based on the trauma site samples was $100 \%$ and $60 \%$ in Lake İnik and Hirfanlı Dam samples, respectively. There was a statistically significant difference between Lake Iznik and Hirfanlı Dam trauma site samples (Cross tabulation $\chi^{2}, p<0.05$ ), with the Hirfanlı Dam population's qPCR rating being skewed towards the lower ratings.

The conformation of the results with conventional PCR method produced high quality PCR amplicons from all six Lake İznik samples and from two Hirfanlı Dam samples (Figure 2). Sequencing of the purified PCR amplicons showed, that these sequences were $100 \%$ identical with public sequences of $A$. astaci (for example EU477364-EU477366, 100\% identity) in $\mathrm{NCBI}$ GenBank, and thereby confirmed the presence of $A$. astaci infection in both Lake İznik and Hirfanlı Dam crayfish populations. 


\section{DISCUSSION}

We detected mostly low to moderate level Aphanomyces astaci DNA in Turkish narrow clawed crayfish (Astacus leptodactylus) in two separate water bodies. Crayfishes were collected from Lake İznik population that had experienced crayfish plague epidemics in mid 1980's (Rahe and Soylu, 1989; Timur, 1990) and later slowly recovered. However, no study has been published on the presence of $A$. astaci in Hirfanlı Dam crayfish population. The results indicate that the narrow clawed crayfish and $A$. astaci could have reached a balance in the previously devastating relationship between native European crayfish and crayfish plague (SoutyGrosset et al., 2006), and the narrow clawed crayfish might not be as susceptible to $A$. astaci infection as has been presumed (Aquiloni et al., 2010). The reasons behind the increased tolerance of the crayfish plague in the narrow clawed crayfish could be due to lowered virulence of the pathogen, increased resistance of the host or both. The fact that Turkish crayfish stocks experienced crayfish plague epidemics only after mid 1980's could have resulted in $A$. astaci been adapted to its European hosts as parasite before Turkish stocks were infected.

Crayfish plague epidemics started in Turkey 1985 and devastated most of the native narrow clawed crayfish stocks. Lake İznik stock has been considered productive before the epidemics and was one of the few stocks that has been producing commercially even after the epidemics, with an estimated annual production of 80-245 ton (Baran and Soylu, 1989b; Balik et al., 2002; Harlioğlu, 2004) and an estimated CPUE from 1.13 to 2.18 in year 2000 survey (Balik et al., 2002). The stock in Lake İznik has shown gross symptoms of infection, melanised lesions and tissue erosion, since 1980's epidemics (Harlioğlu, 2008). The population in Hirfanlı Dam was created by stockings post 1980's crayfish plague epidemics and there are no records of latter crayfish plague epidemics in this crayfish population. At present, Hirfanlı Dam has an estimated annual production of 86-100 ton during 2000's (Harlioğlu, 2004).

Some of the water bodies, such as Lake İznik, that are still productive in Turkey have a specific $\mathrm{Ca}^{2+} / \mathrm{Mg}^{2+}$ ratio and possibly a resulting partial inhibition of $A$. astaci spore formation (Rahe and Soylu, 1989; Rantamäki et al., 1992; Harlioğlu, 2008). This could explain the lowered but still commercial level production of the narrow clawed crayfish in these lakes and the fact that substantial subpopulation survived initial crayfish plague epidemics. The alternative options would be a lowered virulence in $A$. astaci strains currently infecting Turkish crayfish and increased resistance of the host crayfish populations.

The narrow clawed crayfish in Turkish waters commonly express symptoms typical to chronic infection of $A$. astaci (Harlioğlu and Harlioğlu, 2004), similarly to the signal crayfish (Pacifastacus leniusculus). The partial resistance to the $A$. astaci infection can be seen in North American crayfish as melanisation, erosion of tissues and loss of limbs (Nylund and Westman, 2000). Sometimes the signal crayfish dies (Söderhäll and Cerenius, 1999) and stocks even collapse, most probably due to possible multistress situations or multiple infections. Thus, the Turkish narrow clawed crayfish are expressing symptoms typical to crayfish with increased resistance to $A$. astaci. The latent infection has been observed also in the Finnish noble crayfish (Astacus astacus) stocks (Jussila et al., 2011b; Viljamaa-Dirks et al., 2011), where in case of Lake Mikitänjärvi there is commercial fishery in spite of low level detection of $A$. astaci DNA in crayfish indicating chronic infection.

Recent laboratory studies have shown that the noble crayfish could survive Psl-genotype A. astaci infection (Jussila et al., 2011a) and there is further evidence on the increased resistance of the noble crayfish towards some isolates of As-genotype $A$. astaci under laboratory conditions (Makkonen et al., manuscript in preparation). These findings together with the results from the present study strongly suggest that co-evolution between $A$. astaci and native European crayfish, even though very short, has possibly lowered some $A$. astaci genotypes virulence or even increased crayfish resistance towards $A$. astaci. The possibility of an improved balance between this pathogen and its European hosts could open new avenues for breeding of better stocks for both aquaculture and wild stock management. 
The result of our study suggest that the narrow clawed crayfish (A. leptodactylus) populations may well survive $A$. astaci epidemics and recover from a population level collapse despite the continuous presence of the disease. The recovered populations show gross symptoms and mostly low to moderate levels of $A$. astaci DNA in their tissues. This host parasite system works as yet one new example of evolution of decreased parasite virulence or increased host resistance in initially highly unstable host parasite relationship. Our findings further emphasizes the necessity to screen crayfish populations used for management purposes, since the presence of the native European crayfish does not necessary indicate absence of the crayfish plague.

\section{ACKNOWLEDGEMENTS}

Raine Kortet and Anssi Vainikka gave valuable comments. The study was partially funded by the Finnish Ministry of Forestry and Agriculture and by the strategic funding of the University of Eastern Finland. We are thankful to the Turkish crayfishermen for the crayfish.

\section{REFERENCES}

Aquiloni L., Tricarino E. and Gherardi F., 2010. Crayfish in Italy: distribution, threats and management. Int. Aquat. Res., 2, 1-14.

Balik I.E., Özkök E. and Özkök R., 2002. Catch per unit effort and size composition of crayfish, Astacus leptodactylus (Eschscholtz, 1823), in Lake İznik. Asian-Australasian J. Animal Sci., 15, 884-886.

Baran I. and Soylu E., 1989. Crayfish plague in Turkey. J. Fish Dis., 12, 193-197.

Bolat Y., Mazlum Y., Memirci A. and Koca H.U., 2011. Estimating the population size of Astacus leptodactylus (Decapoda: Astacidae) by mark-recapture technique in Eğidir lake, Turkey. Afri J. Biotechnol., 10, 11778-11783.

Güner U. and Harlioğlu M.M., 2010. Status of freshwater crayfish distribution in Thrace region of Turkey. Reviews Fish. Sci., 18, 1-6.

Harlioğlu M.M., 2004. The present situation of freshwater crayfish, Astacus leptodactylus (Eschscholtz, 1823) in Turkey. Aquaculture, 230, 181-187.

Harlioğlu M.M., 2008. The harvest of the freshwater crayfish Astacus leptodactylus Eschscholtz in Turkey: harvest history, impact of crayfish plague, and present distribution of harvested populations. Aquac. Int., 16, 351-360.

Harlioğlu M.M. and Harlioğlu A.G., 2004. The harvest of freshwater crayfish, Astacus leptodactulys (Eschscholtz, 1823) in Turkey. Rev. Fish Biol. Fisher., 14, 415-419.

Harlioğlu M.M. and Harlioglu A.G.I., 2006. Threat of non-native crayfish introductions into Turkey: global lessons. Rev. Fish Biol. Fisher., 16, 171-181.

Holthuis L.B., 1961. Report on a collection of crustacea decapoda and stomatopoda from Turkey and the Balkans, Zoologogische Verhandlingen, Uitgegeven door het Rijksmuseum van Natuurlike Historie te Leiden, Leiden, $69 \mathrm{p}$.

Jussila J., Makkonen J. and Kokko H., 2011a. Peracetic acid (PAA) treatment is an effective disinfectant against crayfish plague (Aphanomyces astaci) spores in aquaculture. Aquaculture, 320, 37-42.

Jussila J., Makkonen J., Vainikka A., Kortet R. and Kokko H., 2011b. Latent crayfish plague (Aphanomyces astaci) infection in a robust wild noble crayfish (Astacus astacus) population. Aquaculture, 321, 17-20.

Kerr P.J. and Best S.M., 1998. Myxoma virus in rabbits. Rev. Sci. Technol., 17, 256-268.

Nylund V. and Westman K., 2000. The prevalence of crayfish plague (Aphanomyces astaci) in two signal crayfish (Pacifastacus leniusculus) populations in Finland. J. Crustacean Biol., 20, 777-785.

Oidtmann B., Geiger S., Steinbauer P., Gulas A. and Hoffmann R.W., 2006. Detection of Aphanomyces astaci in North American crayfish by polymerase chain reaction. Dis. Aquat. Org., 72, 53-64.

Rahe R. and Soylu E., 1989. Identification of the pathogenic fungus causing destruction to Turkish crayfish stocks (Astacus leptodactylus). J. Invertebr. Pathol., 54, 10-15.

Rantamäki J., Cerenius L. and Söderhäll K., 1992. Prevention of transmission of the crayfish plague fungus (Aphanomyces astaci) to the freshwater crayfish Astacus astacus by treatment with $\mathrm{MgCl}_{2}$. Aquaculture, 104, 11-18. 
Söderhäll K. and Cerenius L., 1999. The crayfish plague fungus: history and recent advances. Freshwater Crayfish, 12, 11-35.

Souty-Grosset C., Holdich D.M., Noel D., Reynolds J.D. and Haffner P., 2006. Atlas of crayfish in Europe, Publications Scientifiques du MNHN, Paris, France, $187 \mathrm{p}$.

Strand D.A., Holst-Jensen A., Viljugrein H., Edvardsen B., Klaveness D., Jussila J. and Vrålstad T. 2011. Detection and quantification of the crayfish plague agent in natural waters: direct monitoring approach for aquatic environments. Diseases of Aquatic Organims, 95, 9-17.

Timur G., 1990. Crayfish plague in some lakes of Turkey. Bull. Eur. Ass. Fish Path., 10, 100-103.

Viljamaa-Dirks S., Heinikainen S., Nieminen M., Vennerström P. and Pelkonen S., 2011. Persistent infection by crayfish plague Aphanomyces astaci in a noble crayfish population - a case report. Bull. Eur. Ass. Fish Path., 31, 182-189.

Vrålstad T., Knutsen A.K, Tengs T. and Holst-Jensen A., 2009. A quantitative TaqMan ${ }^{\circledR}$ MGB real-time polymerase chain reaction based assay for detection of the causative agent of crayfish plague Aphanomyces astaci. Vet. Microbiol., 157, 146-155. 